\title{
Silicon Added to Common Bean Seeds: Physiologic and Sanitary Effects
}

\author{
Patricia Migliorini ${ }^{1}$, Andrea Bicca Noguez Martins ${ }^{1}$, Ivan Ricardo Carvalho ${ }^{1}$, Vinícius Jardel Szareski ${ }^{1}$, \\ Sheila Bigolin Teixeira ${ }^{1}$, Jerffeson Araujo Cavalcante ${ }^{1}$, Anna dos Santos Sunne ${ }^{1}$, Alberto Bohn ${ }^{1}$, \\ Ewerton Gewer ${ }^{1}$, Rafael de Oliveira Vergara ${ }^{1}$, Fernanda da Motta Xavier ${ }^{1}$, Daniele Brandstetter Rodrigues ${ }^{1}$, \\ Bruna Barreto dos Reis ${ }^{1}$, Anna dos Santos Sunne ${ }^{1} \&$ Lilian Vanussa Madruga de Tunes ${ }^{1}$ \\ ${ }^{1}$ Departamento de Fitotecnia, Faculdade de Agronomia Eliseu Maciel, Universidade Federal de Pelotas, Pelotas, \\ Rio Grande do Sul, Brazil \\ Correspondence: Ivan Ricardo Carvalho, Departamento de Fitotecnia, Faculdade de Agronomia Eliseu Maciel, \\ Universidade Federal de Pelotas, Pelotas, Rio Grande do Sul, Brazil. E-mail: carvalho.irc@gmail.com
}

\author{
Received: January 24, $2019 \quad$ Accepted: April 25, $2019 \quad$ Online Published: July 31, 2019 \\ doi:10.5539/jas.v11n12p91 URL: https://doi.org/10.5539/jas.v11n12p91
}

\begin{abstract}
The objective of this study was to evaluate the effect of the of common bean seeds coating with different doses of $\mathrm{Si}$, supplied by the carbonized rice hulls, in its physic, physiologic and sanitary attributes, as well determine the amount of this element absorbed in plants. The experiment was conducted in Laboratory of Seed Analysis belonging to the Universidade Federal de Pelotas-Brazil, during the crop season 2014/2015. For this, common bean seeds of cultivar BRS Expedito were treated at doses of 0, 45, 90, 135 and 180 grams of Si $100 \mathrm{~kg}^{-1}$ of seeds, using a completely randomized experimental design with four replicates The use of different doses of carbonized rice hulls in the seed coat does not alter the physical quality and does not negatively affect the physiological quality of the seeds. Crescent doses of carbonized rice hulls up to $101 \mathrm{~g}$ of Si $100 \mathrm{~kg}^{-1}$ of seeds increase the seedlings vigor evaluated by the total dry mass and length of shoot at 21 days after seeding, as well as the $\mathrm{Si}$ amount in roots. The root dry mass at 21 days after seeding presents growth reduction with the increase of doses until $104 \mathrm{~g}$ of Si $100 \mathrm{~kg}^{-1}$ of seeds, although, without compromising the shoot development and the element accumulation. The different Si doses supplied by the carbonized rice hulls do not control pathogens associated to seeds.
\end{abstract}

Keywords: Phaseolus vulgaris, production of seeds, management of nutrients

\section{Introduction}

The adequate management with mineral nutrients supplying, throughout the technique of seeds coating, allied to physic, physiologic, genetic and sanitary quality, propitiate vigorous plants, with adequate and uniform stand. The seeds, by its nature, will have better performance in adverse environmental conditions, in this manner, being fundamental to obtain appropriate yield levels (Corlett et al., 2014; Mondo, Nascente, \& Cardoso Neto, 2016; Rufino et al., 2017).

The distribution uniformity, due to small amounts of nutrients applied during the seeds coating process, makes the element stay in direct contact with the emission of the first roots, meeting the demands during the crop initial development and indirectly aggregating value to the seeds (Tunes et al., 2012). The silicon ( $\mathrm{Si}$ ) is a mineral element that bestow several benefits to the plants and has shown positive results during the initial development of barley (Corlett et al., 2014), rice (Tunes et al., 2014; Oliveira et al. 2016) and soybean (Rufino et al., 2017). Considered potentially benefic or utile to crops, it assists in the plants defense against biotic stresses (disease and pests) and abiotic (stresses by water and salt, toxicity to heavy metals, high radiation, high or low temperature and nutrient imbalance) (Barbosa et al., 2015; Debona, Rodrigues, \& Datnoff, 2017).

Among the most used materials as Si source, are the ones from agro-industrial residues, such as carbonized rice hulls, a sub product of rice industries (Castellanos et al., 2016). It presents an elevated silica content, arousing interest of many researches to seek better uses for this residue (Mendonça, Tavares, Brunes, Monzónm \& Villela, 2013; Tunes et al., 2014; Castellanos et al., 2016; Oliveira et al., 2016; Roma-Almeida et al., 2016). This source can be used in the seeds coating, since it does not harm the germination ability, vigor and sanity of seeds after sowing (Tunes et al., 2014; Oliveira et al., 2016; Rufino et al., 2017). 
The common bean (Phaseolus vulgaris) is considered a plant that does not accumulates Si, mostly when compared to the majority of grasses, which are classified as accumulators of this element (Debona et al., 2017). Although, the benefic effects that Si grants, might not be only related to its accumulation, but can be involved in the activation of biochemical and molecular compounds (Debona et al., 2017; Katz, 2014). Polanco et al. (2014) verified induction of resistance of the common bean against anthracnose (Colletotrichum lindemuthianum), throughout the positive regulation of antioxidant enzymes when the plants were supplied with Si.

This plant is susceptible to many pathogens responsible for significant damages in the fields, among them are the fungus, bacteria, virus and nematodes (Bianchini, Maringoni, \& Carneiro, 2005), which can be associate to seeds and, as consequence, demanding control measures (Carvalho \& Nakagawa, 2012). Studies demonstrate that Si when supplied to rice via seeds, reduce the fungi in tegument incidence (Tunes et al., 2014), thus propitiating more health and vigorous plants (Dallagnol, Rodrigues, \& Mielli, 2013).

In prospect of the environment and consumer health, considering increasing toxic residues from agricultural spraying allied to the potential pathogen damages, a clean technology of low environmental impact becomes an interesting idea if seeking new management strategies. In this manner, studies that indicates the best manner to use this source, enabling the technique of seeds coating, are fundamental to guarantee a good initial performance of common beans. In this context, it was aimed to evaluate the effect of common bean seeds coating with different Si doses, supplied by the carbonized rice hulls, in its physic, physiologic and sanitary attributes, as well determine the amount of this element absorbed in plants.

\section{Material and Methods}

The study was conducted in the Laboratory of Seeds Analysis, Seeds Pathology and in greenhouse of the Eliseu Maciel Agronomy College, of the Universidade Federal de Pelotas, Capão do Leão-RS (Brazil). For this study, common bean seeds of the cultivar BRS Expedito, crop season 2014/15, with initial germination of 82\% were used. The Si source was carbonized rice hulls $(83.54 \% \mathrm{Si})$, previously grinded in mill, with granulometry of \pm 18.2 micrometer and density of $0.58 \mathrm{~g} \mathrm{~cm}^{3}$. The treat was the common bean seeds coating with doses of 0,45 , 90,135 and 180 grams of Si $100 \mathrm{~kg}^{-1}$ of seeds, corresponding to $0,53.9,107.8,161.7$ and 215.7 grams of product for every $100 \mathrm{~kg}$ of seeds.

The process of seeds coating was manually realized, using polyethylene bags as methodology described by Nunes (2005), with four replicates for each dose. So that a certain amount of Si was placed in a bag, plus $300 \mathrm{~mL}$

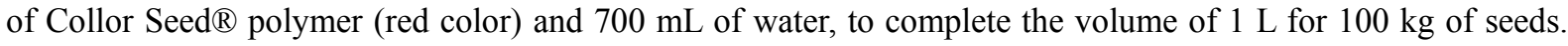
Afterwards, it was homogenized the products in the bottom of the plastic bag, mixing at a height of $15 \mathrm{~cm}$, and then added $0.2 \mathrm{~kg}$ of seeds in each bag, stirring until uniformity of product and total coating of seeds. After the treatment, the bags with seeds were opened allowing the seeds to dry in environmental temperature, for 48 hours, then, the tests were carried out as described next:

Thousand seeds mass (TSM) was determined using four replicates with eight subsamples of 100 seeds from the pure seeds portion and the results expressed in grams (Brasil, 2009a).

Water content (WC) was determined by the kiln method at $105 \pm 3{ }^{\circ} \mathrm{C}$, for 24 hours, in four replicates of five grams of seeds per treat (Brasil, 2009a).

The germination test $(\mathrm{G})$ was carried out with four replicates of 200 seeds, divided in four subsamples of 50 seeds, using substrate germitest paper, wetted with distilled water, in the proportion of 2.5 times the mass of dry paper and maintained in germinator at $25 \pm 2{ }^{\circ} \mathrm{C}$. The evaluations were realized at five and nine days after the test implementation, being the results expressed in percentage of normal seedlings (Brasil, 2009a).

The first germination counting (FGC) was conducted with the $\mathrm{G}$ test, constituting in the register of normal seedlings percentage, verified in the fifth day after sowing (Brasil, 2009a).

The cold test (CT) was conducted in four replicates of 200 seeds, with four subsamples of 50 seeds, distributed in rolls of germitest paper, previously wetted with distilledwater 2.5 times the mass of dry paper. A sequence, the rolls were placed in plastic bags and put in refrigerator regulated at $10^{\circ} \mathrm{C}$ for three days. After, the rolls were placed in germinator at $25 \pm 2{ }^{\circ} \mathrm{C}$, and in the fifth day it was counted the normal seedlings (Guiscem et al., 2010).

The accelerated aging (AA) was conducted in boxes type "gerbox" with aluminum screen overhead in the interior of the box, where the seeds were evenly distributed. The boxes were covered and conditioned inside BOD chamber, with temperature of $43 \pm 1{ }^{\circ} \mathrm{C}$ and staying for a period of 24 hours. After this period, the seeds were germinated, according to the methodology described for the $G$ test (Brasil, 2009a), being the evaluating realized in the fifth day after seeding and the results expressed in percentage of normal seedlings (Bertolin, Sá, \& Moreira, 2011). 
The seedlings total length (STL) was carried out as the FGC, where four subsample of 10 seedlings of each treatment were randomly collected after the fifth day after sowing. The seedlings total length was determined with the aid of a ruler and the results expressed in centimeter (Nakagawa, 1999).

The total seedlings dry matter (SDM) was verified after STL, which were placed in paper bags and dried in kiln of forced air ventilation, at $70{ }^{\circ} \mathrm{C}$ for 72 hours. The SDM was determined in precision scale and results expressed in grams per seedling (Nakagawa, 1999).

For the conduction of the experiments in greenhouse, it was used as substrate earth and vermiculite 2:1 (v/v). The used soil was Planosoil type, with sandy loam texture (Streck et al., 2008), from the Pelotas-RS mapping unit. Chemical characteristics of $\mathrm{pH}$ in $\mathrm{H}_{2} \mathrm{O}$ of $5.0 ; 8.5 \mathrm{mg} \mathrm{dm}^{-3} \mathrm{P} ; 66 \mathrm{mg} \mathrm{dm}^{-3} ; 0.3 \mathrm{cmolc} \mathrm{dm}^{-3} \mathrm{Mg} ; 1.6 \mathrm{cmolc}$ $\mathrm{dm}^{-3} \mathrm{Al} ; 4.2 \mathrm{cmolc} \mathrm{dm}{ }^{-3} \mathrm{H}+\mathrm{Al} ; 0.9 \mathrm{cmolc} \mathrm{dm}{ }^{-3} \mathrm{SB} ; 5.1 \mathrm{mg} \mathrm{dm}^{-3} \mathrm{CTC} ; 17.6 \% \mathrm{~V}$; MO $16.4 \mathrm{~g} \mathrm{dm}^{-3}$ and $6 \mathrm{mg} \mathrm{kg}^{-1} \mathrm{of}^{-3}$ Si.

The seedling emergence (SE) was determined with four replicates of 50 seeds for each treatment, sowed in plastic tray, depth of $2.0 \mathrm{~cm}$ containing earth and vermiculite, maintained in greenhouse without control of temperature but irrigated. The evaluation was realized at 21 DAS computing in percentage the number of emerged normal seedlings (Nakagawa, 1999).

The velocity of emergence index (VEI) was carried out with the SE, throughout daily counting of emerged seedlings until the emergence be still. For each replicate was calculated the VEI, adding the number of emerged seedlings every day and dividing by the number of days from the seeding (Maguire, 1962).

The root length (RL21d) and shoot length (SL21d) was determined in 20 normal seedlings randomly choose from each replicate, at the end of SE evaluation and measured with ruler, expressed in $\mathrm{cm}$ per seedling.

The root dry matter (RDM21d) and shoot dry matter at 21 days (SDM21d) were determined in seedlings of the RL21d and SL21d, which were then separated and put to dry in kiln of forced air circulation at $70{ }^{\circ} \mathrm{C}$, for 72 hours. After this period, the samples were weighted in precision analytic balance and the results expressed in grams per seedling.

Seedlings resultant from SE were removed from the substrate, washed and immediately discriminated in root, hypocotyl and leaves. Then, it were placed in paper bags and dried at $70{ }^{\circ} \mathrm{C}$ for 72 hours. Afterwards, they were grinded in electric mill type Willey, Marconi ${ }^{\circledR}$ with sieves of 40 mesh. The amount of Si concentration in the tissues was determined by the colorimetric analysis in $0.1 \mathrm{~g}$ of dry tissue, after basic ingestion (Korndörfer, Pereira, \& Nola, 2004).

The evaluation was realized through the "Blotter Test" method freezing for 24 hours, using 200 seeds for each treatment, divided in four subsamples of 50 seeds, which were placed in plastic boxes "gerbox" type previously disinfested with alcohol $70 \%$ and sodium hypochlorite at $1 \%$, containing two filter paper sheets sterilized and wetted with distilled water. After frozen, the seeds were incubated at $25{ }^{\circ} \mathrm{C}$ for seven days with light/dark period of 12 hours (Brasil, 2009b). The seeds individual evaluation was realized with microscope stereoscopic and optic, being the pathogens identified at genre level (Barnett \& Hunter, 1972), and the results expressed in percentage of infested seeds.

The experimental design was completely randomized with four replicates. For the statistical analysis, the data was submitted to residue normality test by Shapiro-Wilk and variances homogeneity by Bartlett. When attending the presuppositions, the data were submitted to variance analysis (ANOVA) and if significant, were realized polynomial regression equations. The Kruskal-Wallis test was used for non-parametric data. The analysis were processed by the SAS Software (SAS Institute, 1989, Cary, NC).

\section{Results and Discussion}

The results obtained and the equations of regression for the variables physic and physiologic quality of seeds, as well the amount of Si concentration in common bean seedlings, from seeds coated with different doses of carbonized rice hulls, can be found in Table 1 . The physic quality of seeds was not significantly influenced by $\mathrm{Si}$ doses, as verified in the variables TSM and WC (Table 1). 
Table 1. Regression of silicone doses, for the variables of physic and physiologic quality of seeds and silicon concentration in roots, hypocotyl and leaves of common beans from seeds coated with carbonized rice hulls

\begin{tabular}{|c|c|c|c|c|c|c|c|c|c|c|c|}
\hline \multirow{2}{*}{ Evaluation } & \multicolumn{5}{|c|}{ Si dose (g $100 \mathrm{~kg}^{-1}$ of seeds) } & \multirow{2}{*}{$-\operatorname{Pr}>F$} & \multirow{2}{*}{ CV $(\%)$} & \multirow{2}{*}{ Regression equation } & \multirow{2}{*}{$\mathrm{R}^{2}$} & \multirow{2}{*}{ Ideal dose } & \multirow{2}{*}{$Y_{E}$} \\
\hline & 0 & 45 & 90 & 135 & 180 & & & & & & \\
\hline \multicolumn{12}{|l|}{ Qualidade física } \\
\hline TSM (g) & 245.32 & 248.44 & 245.94 & 248.28 & 247.59 & ns & - & - & - & - & - \\
\hline WC $(\%)$ & 5.0 & 4.9 & 4.9 & 4.9 & 4.9 & ns & - & - & - & - & - \\
\hline \multicolumn{12}{|l|}{ Qualidade fisiológica } \\
\hline FGC $(\%)$ & 82 & 77 & 74 & 74 & 76 & ns & - & - & - & - & - \\
\hline $\mathrm{G}(\%)$ & 82 & 83 & 83 & 81 & 82 & ns & - & - & - & - & - \\
\hline AA $(\%)$ & 72 & 73 & 65 & 65 & 66 & ns & - & - & - & - & - \\
\hline CT $(\%)$ & 80 & 80 & 76 & 80 & 80 & ns & - & - & - & - & - \\
\hline STL (cm/seedling) & 19.62 & 18.99 & 20.07 & 20.03 & 18.16 & ns & - & - & - & - & - \\
\hline SDM (g/seedling) & 0.05 & 0.05 & 0.06 & 0.05 & 0.05 & * & 15.98 & $y=0.0457+0.00019 x-0.0000011 x^{2}$ & 0.63 & 100 & 0.06 \\
\hline $\mathrm{SE}(\%)$ & 85 & 87 & 86 & 87 & 85 & ns & - & - & - & - & - \\
\hline VEI & 6.44 & 6.39 & 6.11 & 6.06 & 5.75 & $*$ & 3.36 & $y=6.49544-0.00385 x$ & 0.90 & - & - \\
\hline SL21d (cm/seedling) & 28.44 & 31.84 & 30.58 & 29.40 & 29.98 & * & 3.02 & $y=29.12100+0.03679 x-0.00019630 x^{2}$ & 0.35 & 94 & 30.84 \\
\hline RL21d (cm/seedling) & 16.88 & 14.67 & 14.80 & 15.41 & 15.85 & $\mathrm{~ns}$ & - & - & - & - & - \\
\hline SDM21d(g/seedling) & 0.24 & 0.23 & 0.25 & 0.25 & 0.26 & ns & - & - & - & - & - \\
\hline RDM21d (g/seedling) & 0.09 & 0.07 & 0.08 & 0.06 & 0.08 & * & 13.80 & $y=0.08892-0.00039702 x+0.00000191 x^{2}$ & 0.54 & 104 & 0.07 \\
\hline \multicolumn{12}{|c|}{ Siliconconcentration $\left(\mathrm{g} \mathrm{kg}^{-1}\right)$} \\
\hline Root & 8.63 & 11.14 & 12.29 & 10.66 & 10.40 & * & 10.17 & $y=8.82957+0.05952 x-0.00029295 x^{2}$ & 0.83 & 101 & 11.85 \\
\hline Hypocotyl & 2.29 & 2.41 & 1.86 & 2.00 & 1.96 & ns & - & - & - & - & - \\
\hline Leaf & 3.14 & 3.60 & 3.45 & 3.52 & 3.81 & ns & - & - & - & - & - \\
\hline
\end{tabular}

Note. $*$ and $\mathrm{ns}=$ significant and non-significant by $\mathrm{F}$ test at $5 \%$ probability, respectively; $\mathrm{R}^{2}=$ determination coefficient; $\mathrm{Y}$ and = estimated value by the ideal Si dose. Thousand seeds mass (TSM); water content (WC); first germination counting (FGC); germination (G); cold test (CT); accelerated aging (AA); seedlingstotal length (STL), seedlings dry matter (SDM); seedlings emergence (SE); velocity emergence index (VEI); shoot length (SL21d) and root length (RL21d) of seedlings at 21 days; shoot dry matter (SDM21d) and root dry matter (RDM21) at 21 days.

The process of seed coating did not change the weight and physic layer of the seeds, because the source used for it (carbonized rice hulls) had a fine texture, lightweight and low density texture. However, weight increases of $0.62(0.25 \%)$ to $3.12(1.25 \%)$ were observed in relation to the zero dose. According to Silva and Nascimento (2009), the addition of products with very small doses and densities do not significantly modify the physic proprieties of the coating layer. In this manner, materials with good adhesion and solubility are preferred, in order to guarantee gas exchanges and water absorption between the seed and the external environment of the coating, although, without interfering in the germinating process (Xavier, Vieira, \& Guimarães, 2015).

In relation to $\mathrm{WC}$, seed moisture did not change with the application of the different doses of $\mathrm{Si}$, the polymer and water used in the coating process, being adequate the time and environmental temperature used in the process of seeds drying, what possibly proportionate a safe storage, since the seeds will not absorb water (Xavier et al., 2015). There was no significant difference in the percentage of normal seedlings, obtained by the FGC, G, AG and CT tests, by increasing the Si doses in the seed coat, demonstrating that the use of carbonized rice hulls does not harmed the development of normal seedlings, as much for ideal germinating conditions as for stress conditions (Table 1). Similar results were found in coated seeds of barley, wheat and rice (Tavares et al., 2012, 2014; Corlett et al., 2014; Tunes et al., 2014). However, Oliveira et al. (2016) verified that improved Si doses propitiate increase in the number of normal seedlings for FGC in rice.

The STL was not influenced by Si doses (Table 1). Although, positive and significant results are verified in the production of SDM, being the data adjusted to a quadratic behavior, where the maximum point of dry matter accumulation was at the dose of $100 \mathrm{~g} \mathrm{Si} 100 \mathrm{~kg}^{-1}$ of seeds, resulting in the increase of $16 \%$ in relation to zero dose (Table 1). These results agree with other studies, which demonstrated that $\mathrm{Si}$ is a benefic element, that positively influences the growth rate and seedling development at initial stages when supplied with seeds coating 
(Tavares et al., 2012; Tunes et al., 2014; Corlett et al., 2014; Janmohammadi \& Sabaghnia, 2015; Rufino et al., 2017).

As for the data obtained from greenhouse, it was verified decreasing linear behavior with the increase in doses. Although not show any significant change at the final percentage of SE (Table 1). These results reveals the compromising of the ability to rapid emerge with the increase in the doses, although, without affecting the final establishment of the stand. Tavares et al. (2012) and Corlett et al. (2014) verified that, the seeds coating with Si did not compromised the seedlings emergence of rice and barley, respectively. While Tunes et al. (2014) stated linear rise in seedlings emerged with the increase of Si doses. Studies with Si nanoparticles in seeds demonstrate that the benefic effects proportioned by this element are more pronounced in low concentrations, since, by increasing the concentration within the seeds, it accumulates in the epidermal tissues, bettering the cell wall sustainability, but, retarding the radicle emission and seeds germination, consequently, de seedlings development (Janmohammadi \& Sabaghnia, 2015). On the other hand, this cell wall fortification, just as in the activation of biochemical compounds of $\mathrm{Si}$, confers resistance to the plants against biotic and abiotic stresses (Debona et al., 2017).

For the SL21d, it is observed that the data adjusted to a quadratic positive model, being the ideal dose obtained with $94 \mathrm{~g}$ of Si $100 \mathrm{~kg}^{-1}$ of seeds, generating a growth expectation of 7.7\% more in relation to zero dose (Table 1), and thus, demonstrating that the shoot growth was favored with the Si doses. However, there was no significant difference for RL21d and SDM21d, for increasing doses of Si (Table 1). It is worth to emphasize that the higher seedlings growth can increment the exploitation of the solar radiation available in the begging of the cycle, being important for the photosynthetic process, as well as well-developed roots will propitiate larger area of exploration and acquisition of water and nutrients (Taiz \& Zeiger, 2013).

For the variable RDM21d, the results found were adjusted to a negative quadratic model, where the increase in Si doses had its minimum point at $104 \mathrm{~g}$ of Si $100 \mathrm{~kg}^{-1}$ of seeds, although, not compromising the shoot development (Table 1). Similar effect was observed by Ribeiro et al. (2011) in coffee seedlings and Farias Júnior et al. (2009) in rice, when the plants were supplied with elevated Si doses.

In relation to the $\mathrm{Si}$ concentration in roots, it is observed that the data were adjusted to a positive quadratic equation, and when submitted to the dose of $101 \mathrm{~g}$ of Si $100 \mathrm{~kg}^{-1}$ of seeds, presented an increase of $27.17 \%$ in relation to the zero dose. For the concentration of $\mathrm{Si}$ in hypochlorite and leaf, there were no significant differences between the doses (Table 1). According to Mitani and ma (2005), the species of plants classified as non-accumulating, as common beans, have a lower number of Si transporters in the apoplast and symplast, and a failure of the Si transporters of cortical cells to the xylem, what explains the larger Si concentration in the radicular system instead of the shoot area.

By the sanitary analysis, it was possible to detect, in common bean seeds coated by carbonized rice hulls, fungus as Fusarium sp., Alternaria sp. and Colletotrichum sp., and fungus from storage Peniillium sp., and Aspergillus sp. (Tables 2 and 3). These fungi were considered pathogenic to common beans, which caused seeds deterioration, roots and stem rottenness, wilt, necrosis and seedlings death (Marcenaro \& Valkonen, 2016).

Table 2. Pathogen incidence in common bean seeds coated with carbonized rice hulls

\begin{tabular}{|c|c|c|c|c|c|c|c|c|}
\hline \multirow{2}{*}{ Incidence (\%) } & \multicolumn{5}{|c|}{ Si dose (g $100 \mathrm{~kg}^{-1}$ of seeds) } & \multirow{2}{*}{ - Mean } & \multirow{2}{*}{$\operatorname{Pr}>F$} & \multirow{2}{*}{$\mathrm{CV}(\%)$} \\
\hline & 0 & 45 & 90 & 135 & 180 & & & \\
\hline Penicillium sp. & 9.50 & 18.00 & 19.50 & 14.00 & 10.50 & 14.30 & $*$ & 35.05 \\
\hline \multirow[t]{2}{*}{ Alternaria sp. } & 19.00 & 10.50 & 15.50 & 10.50 & 8.00 & 12.70 & * & 38.84 \\
\hline & \multicolumn{4}{|c|}{ Regressionequation } & $\mathrm{R}^{2}$ & \multicolumn{2}{|c|}{ Ideal dose } & $\mathrm{Y}_{\mathrm{E}}$ \\
\hline Penicillium sp. & \multicolumn{4}{|c|}{$\mathrm{y}=10.27143+0.19238 \mathrm{x}-0.00109 \mathrm{x}^{2}$} & 0.88 & 88 & & 18.75 \\
\hline Alternaria sp. & \multicolumn{4}{|c|}{$\mathrm{y}=17.10000-0.04889 \mathrm{x}$} & 0.61 & - & & - \\
\hline
\end{tabular}

Note. $*$ and $\mathrm{ns}=$ significant and non-significant by $\mathrm{F}$ test at $5 \%$ probability. 
Table 3. Pathogen incidence in common bean seeds coated with carbonized rice hulls

\begin{tabular}{lllllll}
\hline \multirow{2}{*}{ Incidence (\%) } & \multicolumn{7}{c}{ Si dose $\left(\mathrm{g} 100 \mathrm{~kg}^{-1}\right.$ of seeds) } \\
\cline { 2 - 6 } & 0 & 45 & 90 & 135 & 180 & Mean \\
\hline Fusarium sp. & $79.50^{\mathrm{ns}}$ & 78.00 & 74.50 & 87.50 & 86.50 & 81.20 \\
Colletotrichum sp. & $0.50^{\mathrm{ns}}$ & 0.00 & 0.00 & 0.00 & 0.00 & 0.10 \\
Aspergillus sp. & $20.50^{\mathrm{ns}}$ & 5.50 & 12.00 & 4.00 & 4.00 & 9.20 \\
\hline
\end{tabular}

Note. *Mean followed by the same letter in line do not differ among themselves $(\mathrm{P}>0.01)$ according Kruskal-Wallis test. ns: non-significant.

For the Penicillium sp. incidence, the data adjusted to a quadratic positive model in function of Si doses, achieving the maximum point in the dose of $88 \mathrm{~g}$ of Si $100 \mathrm{~kg}^{-1}$ of seeds (Table 2). For Alternaria sp. there was a reduction in incidence with the increase of doses, which presented a decreasing linear behavior, a reduction of $58 \%$ in relation to the zero dose was observed at the highest dose (Table 2). Benefic results of the Si utilization were verified by Dallagnol et al. (2013) in the reduction of Bipolarisoryzae in rice seedlings, and by Tunes et al. (2016), in the control of fungus incidence in seeds. However, Roma-Almeida et al. (2016) did not find reduction in pathogens incidence in rice seeds produced under different doses and sources of Si. Fusarium sp., Colletotrichum sp. and Aspergillus sp do not present significant differences to the coating in different doses, but was observed a higher percentage mean of incidence to Fusarium sp. (81.2\%) between the pathogens associated with common bean seeds, coated with carbonized rice hulls (Table 3). Mambrin et al. (2015) also verified the presence of this genre, mostly in common bean lines produced in the central region of Rio Grande do Sul state.

The common bean seeds coating with Si did not eliminate pathogens associated with seeds, which in its majority occurred sporadically within the Si doses (Tables 2 and 3). Conversely, Si has been used in the control of diseases in many pathosystems, contributing in the integrated control strategies, throughout the increase of plant resistance through mineral fertilizing, which collaborates to the reduction in the usage of fungicides in the agriculture (Marodinet al., 2014).

The coating process is environmentally less aggressive technique, which favors the micronutrient contact with the first issued roots, during the germination and seedlings emergence (Tunes et al., 2012; Corlett et al., 2014). The nutrients, though, must be easily absorbed by the radicular system, in order to propitiate better conditions to a fast and vigorous growth. In this manner, the seedlings may avoid initial infection caused by pathogens that are associated with seeds, just as the same for those present in the soil, mostly during initial development (Corlett et al., 2014; Tuneset al., 2014; Lamichhane et al., 2017).

\section{Conclusions}

The seeds coating with different doses of carbonized rice hulls does not modify the physic quality and does not negatively affects the physiologic quality of seeds.

Crescent doses of carbonized rice hulls up to $101 \mathrm{~g}$ of Si $100 \mathrm{~kg}^{-1}$ of seeds increase the seedlings vigor evaluated by the total dry mass and length of shoot at 21 days after seeding, as well as the Si amount in roots.

The root dry mass at 21 days after seeding presents growth reduction with the increase of doses until $104 \mathrm{~g}$ of Si $100 \mathrm{~kg}^{-1}$ of seeds, although, without compromising the shoot development and the element accumulation. The different Si doses supplied by the carbonized rice hulls do not control pathogens associated with the seeds.

\section{References}

Barbosa, M. A. M., Silva, M. H. L., Viana, G. D. M., Ferreira, T. R., Carvalho Souza, C. L. F., Lobato, E. M. S. G., \& Silva Lobato, A. K. (2015). Beneficial repercussion of silicon (Si) application on photo syn the tic pigments in maize plants. Australian Journal of Crop Science, 9(11), 1113-1118.

Barnet, H. L., \& Hunter, B. B. (1972). Ilustrated genera of imperfect fungi (3rd ed., p. 241). Minneapolis: Burgess.

Brasil, Ministério da Agricultura, Pecuária e Abastecimento. (2009a). Regras para Análise de Sementes (p. 399). Brasília: Mapa/ACS.

Brasil, Ministério da Agricultura, Pecuária e Abastecimento. (2009b). Manual de Análise Sanitária de Sementes (p. 200). Brasília: Mapa/ACS.

Bertolin, D. C., Sá, M. E., \& Moreira, E. R. (2011). Parâmetros do teste de envelhecimento acelerado para determinação do vigor de sementes de feijão. Revista Brasileira de Sementes, 33(1), $104-112$. https://doi.org/10.1590/S0101-31222011000100012 
Bianchini, A., Maringoni, A. C., \& Carneiro, S. M. T. P. G. (2005). Doenças do Feijoeiro. In H. Kimati, L. Amorim, J. A. M. Rezende, A. Bergamin Filho, \& L. E. A. Camargo (Eds.), Manual de fitopatologia: Doenças das plantas cultivadas (4th ed., pp. 333-349). São Paulo: Agronômica Ceres.

Carvalho, N. M., \& Nakagawa, J. (2012). Sementes: Ciência, tecnologia e produção (5th ed., p. 590). Jaboticabal: FUNEP. https://doi.org/10.1590/S0101-31222012000200011

Castellanos, C. I. S., Rosa, M. P., Deuner, C., Bohn, A., Barros, A. C. S. A., \& Meneghello, G. E. (2016). Aplicação ao solo de cinza de casca de arroz como fonte de silício: Efeito na qualidade de sementes de trigo produzidas sob stresse salino. Revista de Ciências Agrárias, 39(1), 95-104. https://doi.org/10.19084/ RCA15011

Conceição, P. M., \& Vieira, H. D. (2008). Qualidade fisiológica e resistência do recobrimento de sementes de milho. Revista Brasileira de Sementes, 30, 48-53. https://doi.org/10.1590/S0101-31222008000300007

Corlett, F. M. F., Rufino, C. A., Vieira, J. F., Tavares, L. C., Tunes, L. V. M., \& Barros, A. C. S. A. (2014). The influence of seed coating on the vigor and early seedling growth of barley. Ciencia Investigación Agraria, 41(1), 29-136. https://doi.org/10.4067/S0718-16202014000100013

Dallagnol, L. J., Rodrigues, F. A., \& Mielli, M. V. B. (2013). Silicon improves the emergence and sanity of rice seedlings obtained from seeds infected with Bipolaris oryzae. Tropical Plant Pathology, 38(6), 478-484. https://doi.org/10.1590/S1982-56762013000600003

Debona, D., Rodrigues, F. A., \& Datnoff, L. E. (2017). Silicon's role in abiotic and biotic plant stresses. Annual Review of Phytopathology, 55, 85-107. https://doi.org/10.1146/annurev-phyto-080516-035312

Faria Junior, L. A., Carvalho, J. G., Pinho, P. J., Bastos, A. R. R., \& Ferreira, E. V. (2009). Produção de matéria seca, teor e acúmulo de silício em cultivares de arroz sob doses de silício. Ciência e Agrotecnologia, 33(4), 1034-1040. https://doi.org/10.1590/S1413-70542009000400013

Guiscem, J. M., Farias, A. S., Figueiredo, R. T., Chaves, A. M. S., Figueiredo, B. T., Pereira, C. F., ... Martins, M. R. (2010). Teste de frio e envelhecimento acelerado na avaliação de vigor de sementes de feijão-frade. Revista de Ciências Agrárias, 33(2), 182-191.

Janmohammadi, M., \& Sabaghnia, N. (2015). Effect of pre-sowing seed treatments with silicon nanoparticles on germinability of sunflower (Helianthus annuus). Botanica Lithuanica, 21(1), 13-21. https://doi.org/10.1515/ botlit-2015-0002

Korndörfer, G. H., Pereira, H. S., \& Nola, A. (2004). Análise de silício: Solo, planta e fertilizante. Uberlândia: GPSi-ICIAG-UFU.

Katz, O. (2014). Beyond grasses: The potential benefits of studying silicon accumulation in non-grass species. Frontiers in Plant Science, 5. https://doi.org/10.3389/fpls.2014.00376

Lamichhane, J. R., Dürr, C., Schwanck, A. A., Robin, M. H., Sarthou, J. P., Cellier, V., ... Aubertot, J. N. (2017). Integrated management of damping-off diseases: A review. Agronomy for Sustainable Development, 37(10), 1-25. https://doi.org/10.1007/s13593-017-0417-y

Marodin, J. C., Resende, J. T., Morales, R. G. F., Silva, M. L. S., Galvão, A. G., \& Zanin, D. S. (2014). Yield of tomato fruits in relation to silicon sources and rates. Horticultura Brasileira, 32(2), 220-224. https://doi.org/ 10.1590/S0102-05362014000200018

Mambrin, R. B., Ribeiro, N. D., Henning, L. M. M., Henning, F. A., \& Barkert, K. A. (2015). Seleção de linhagens de feijão com base no padrão e na qualidade de sementes. Revista Caatinga, 28(3), 147-156. https://doi.org/ $10.1590 / 1983-21252015 \mathrm{v} 28 \mathrm{n} 317 \mathrm{rc}$

Maguire, J. (1962). Speed of germination aid in selection and evolution for seedling and vigour. Crop Science, 2(2), 176-177. https://doi.org/10.2135/cropsci1962.0011183X000200020033x

Marcenaro, D., \& Valkonen, J. P. T. (2016). Seedborne pathogenic fungi in common bean (Phaseolus vulgaris cv. INTA Rojo) in Nicaragua. PLoS ONE, 11(12), 1-18. https://doi.org/10.1371/journal.pone.0168662

Mendonça, A. O., Tavares, L. C., Brunes, A. P., Monzónm, D. L. R., \& Villela, F. A. (2013). Acúmulo de silício e compostos fenólicos na parte aérea de plantas de trigo após a adubação silicatada. Bioscience Journal, 29(5), 1154-1162.

Mitani, N., \& Ma, J. F. (2005). Uptake system of silicon in different plant species. Journal of Experimental Botany, 56, 1255-1261. https://doi.org/10.1093/jxb/eri121 
Mondo, V. H. V., Nascente, A. S., \& Cardoso Neto, M. O. (2016). Common bean seed vigor affecting crop grain yield. Journal of Seed Science, 38(4), 365-370. https://doi.org/10.1590/2317-1545v38n4166814

Nakagawa, J. (1999). Testes de vigor baseados no desempenho das plântulas. In F. C. Krzyzanowski, R. D. Vieira, \& J. B. França Neto (Eds.), Vigor de sementes: Conceitos e testes (pp. 2-21). Londrina: ABRATES.

Nunes, J. C. (2005). Tratamento de semente-qualidade e fatores que podem afetar a sua performance em laboratório (p. 16). São Paulo: Syngenta Proteção de Cultivos Ltda.

Oliveira, S., Brunes, A. P., Lemes, E. S., Tavares, L. C., Meneghello, G. E., Leitzke, I. D., \& Mendonça, A. O. (2016). Tratamento de sementes de arroz com silício e qualidade fisiológica das sementes. Revista de Ciências Agrárias, 39(2), 202-209. https://doi.org/10.19084/RCA15083

Polanco, L. R., Rodrigues, F. A., Nascimento, K. J. T., Cruz, M. F. A., Curvelo, C. R. S., Damatta, F. M., \& Vale, F. X. R. (2014). Photosyn the ticgasex change and antioxidative system in common bean plants infected by Colletotrichum lindemuthianum and supplied withsilicon. Tropical Plant Pathology, 39(1), 35-42. https://doi.org/10.1590/S1982-56762014000100005

Ribeiro, R. V., Silva, L., Ramos, R. A., Andrade, C. A., Zambrosi, F. C. B., \& Pereira, S. P. (2011). O alto teor de silício no solo inibe o crescimento radicular de cafeeiros sem afetar as trocas gasosas foliares. Revista Brasileira de Ciência do Solo, 35(3), 939-948. https://doi.org/10.1590/S0100-06832011000300028

Roma-Almeida, R. C. C., Pereira, O. L., Dias, D. C. F. S., Prabhu, A. S., Filippi, M. C. C., Duarte, H. S. S., \& Rodrigues, F. A. (2016). Efeito da aplicação de silicato de cálcio e de cinza de casca de arroz sobre a incidência de fungos associados a manchas em sementes de arroz irrigado. SummaPhytopathol, 42(1), 73-78. https://doi.org/10.1590/0100-5405/2108

Rufino, C. A., Tavares, E. C., Ramos, P. M., Vieira, J. F., Abreu Junior, J. S., Silva, F. J. A.,... Gil, J. M. (2017). Performance of soybean seedlings upon nutriente aplication by seed coating. Brazilian Archives of Biology and Technology, 60, 1-11. https://doi.org/10.1590/1678-4324-2017160128

Silva, J. B. C., \& Nascimento, W. M. (2009). Peletização de sementes de hortaliças. In W. M. Nascimento (Ed.), Tecnologia de sementes de hortaliças (pp. 309-341). Brasília: Embrapa Hortaliças.

Streck, E. V., Kämpf, N., Dalmolin, R. S. D., Klamt, E., Nascimento, P. C., Schneider, P., ... Pinto, L. F. S. (2008). Solos do Rio Grande do Sul (2nd ed., p. 222). Porto Alegre: Emater/RS.

Taiz, L., \& Zeiger, E. (2013). Fisiologia vegetal (5th ed., p. 918). Artmed: Porto Alegre.

Tavares, L., Tunes, L., Mendonça, A., Lemes, E., Salinas, J., Barros, A. C., \& Meneghello, G. (2014). Alteraciones fisiológicas y enzimáticas ensemillas de trigo (Triticumaestivum L.) recubiertas consilicio. Revista de Agricultura, 89(3), 199-211.

Tavares, L. C., Rufino, C. A., Dörr, C. S., Barros, A. C. S. A., \& Peske, S. T. (2012). Performance of lowland rice seeds coated with dolomitic limestone and aluminum silicate. Revista Brasileira de Sementes, 34(2), $202-211$. https://doi.org/10.1590/S0101-31222012000200003

Tunes, L. M., Pedroso, D. C., Tavares, L. C., Barbieri, A. P. P., Barros, A. C. S. A., \& Muniz, M. F. B. (2012). Tratamento de sementes de trigo com zinco: Armazenabilidade, componentes do rendimento e teor do elemento nas sementes. Ciência Rural, 42(7), 1141-1146. https://doi.org/10.1590/S0103-84782012000 700001

Tunes, L. V. M., Fonseca, D. A. R., Meneghello, G. E., Reis, B. B., Brasil, V. D., Rufino, C. A., \& Villela, F. A. (2014). Qualidade fisiológica, sanitária e enzimática de sementes de arroz irrigado recobertas com silício. Revista Ceres, 61(5), 675-685. https://doi.org/10.1590/0034-737X201461050011

Xavier, P. B., Vieira, H. D., \& Guimarães, C. P. (2015). Physiological potential of Stylosanthes cv. Campo Grande seeds coated with different materials. Journal of Seed Science, 37(2), 117-124. https://doi.org/10.1590/ 2317-1545v37n2145982

\section{Copyrights}

Copyright for this article is retained by the author(s), with first publication rights granted to the journal.

This is an open-access article distributed under the terms and conditions of the Creative Commons Attribution license (http://creativecommons.org/licenses/by/4.0/). 